\title{
Update on Neuromodulation for Treatment-Resistant
}

\section{Depression [version 1; peer review: 3 approved]}

\author{
Bettina Bewernick1, Thomas E Schlaepfer ${ }^{1,2}$ \\ ${ }^{1}$ Department of Psychiatry and Psychotherapy, University Hospital, Bonn, Germany \\ ${ }^{2}$ Departments of Psychiatry and Mental Health, Johns Hopkins University, Baltimore, USA
}

V1 First published: 02 Dec 2015, 4(F1000 Faculty Rev):1389

https://doi.org/10.12688/f1000research.6633.1

Latest published: 02 Dec 2015, 4(F1000 Faculty Rev):1389

https://doi.org/10.12688/f1000research.6633.1

\section{Abstract}

About $30 \%$ of patients suffering from a major depressive disorder do not respond sufficiently to established pharmacological, psychotherapeutic, or somatic treatments. Advances in technology and emerging knowledge about the dysfunctional brain circuits underlying depression have led to the development of different neuromodulation techniques. The aim of the present review is to give an update on noninvasive techniques, such as electroconvulsive therapy (ECT), magnetic seizure therapy (MST), transcranial magnetic stimulation (TMS), and invasive techniques requiring brain surgery, such as vagus nerve stimulation (VNS) and deep brain stimulation (DBS). First, the clinical relevance for therapy-resistant depression, including the current level of evidence, are presented.

Neuroethics is concerned with the ethical, legal and social policy implications of neuroscience. A second focus of the review is the application of fundamental ethical principles, such as patient autonomy, patient well-being and justice to neuromodulation therapies. Due to reduced availability and lacking long-term efficacy data, most patients with treatment-resistant depression face a trialand-error approach to therapeutics. This contravenes the ethical criteria of patient autonomy and justice. In order to raise the level of evidence, financial support of long-term studies, including large samples and randomized control trials, are necessary.

\section{Keywords}

Depression, vagus nerve, seizures

\section{Open Peer Review \\ Approval Status \\ 1 \\ 2 \\ 3 \\ version 1 \\ 02 Dec 2015 \\ Faculty Reviews are review articles written by the prestigious Members of Faculty Opinions. The articles are commissioned and peer reviewed before publication to ensure that the final, published version is comprehensive and accessible. The reviewers who approved the final version are listed with their names and affiliations. \\ 1. Pierre Blier, University of Ottawa, Ottawa, Canada}

2. Allan Young, King's College London, London, UK

3. Michael Thase, University of Pennsylvania, Philadelphia, USA Any comments on the article can be found at the end of the article. 
Corresponding author: Thomas E Schlaepfer (schlaepf@jhmi.edu)

Competing interests: No funding specifically for conducting this review has been obtained. TS received partial funding for an investigator-initiated study on DBS for major depression from Medtronic Inc. TS is chair of the project group Deep Brain Stimulation in Psychiatry: Guidance for Responsible Research and Application, funded by the Volkswagen Foundation (Hanover, Germany). TS and BB are members of the working group Neuromodulation of the German Research Foundation.

Grant information: The author(s) declared that no grants were involved in supporting this work.

Copyright: @ 2015 Bewernick B and Schlaepfer TE. This is an open access article distributed under the terms of the Creative Commons Attribution License, which permits unrestricted use, distribution, and reproduction in any medium, provided the original work is properly cited.

How to cite this article: Bewernick B and Schlaepfer TE. Update on Neuromodulation for Treatment-Resistant Depression [version 1; peer review: 3 approved] F1000Research 2015, 4(F1000 Faculty Rev):1389 https://doi.org/10.12688/f1000research.6633.1

First published: 02 Dec 2015, 4(F1000 Faculty Rev):1389 https://doi.org/10.12688/f1000research.6633.1 


\section{Introduction}

About $30 \%$ of patients suffering from a major depressive disorder do not respond sufficiently to established pharmacological, psychotherapeutic, or somatic treatments ${ }^{1}$. After nonresponse to two adequate treatment steps, a patient is described as having a treatment-resistant depression, which is associated with illness chronicity, a reduced quality of life, and a higher risk for suicide ${ }^{2}$. The grade of treatment resistance can be evaluated using different models, for example the antidepressant treatment history form ${ }^{3}$, or the Thase and Rush Model ${ }^{4}$. A substantial quota of patients with treatment-resistant depression have an anamnesis of multiple pharmacological and psychological treatment attempts and patients, as well as treating psychiatrists, are desperate for alternative approaches. Patients with treatment-resistant depression cannot be cured quickly ${ }^{5}$ and $20-80 \%$ of patients suffering from treatmentresistant depression face a relapse within 5 years, in spite of maintenance therapy ${ }^{1,6-9}$. It is therefore necessary to evaluate long-term effects (more than 5 years of treatment) in order to be able to assess the risk-benefit ratio for new treatment methods.

\section{Neuromodulation}

Advances in technology and emerging knowledge about the dysfunctional brain circuits underlying depression have led to the development of different neuromodulation techniques. All these techniques attempt to change the brain's neuronal activity in a more or less focal way. For treatment-resistant patients suffering from major depression, neuromodulation techniques offer a therapeutic option.

In this review, noninvasive techniques, such as electroconvulsive therapy (ECT), magnetic seizure therapy (MST), transcranial magnetic stimulation (TMS), and invasive techniques requiring brain surgery, such as vagus nerve stimulation (VNS) and deep brain stimulation (DBS), are described. The clinical relevance for therapy-resistant depression, including the current level of evidence, is discussed ${ }^{10}$.

\section{Neuroethics}

Neuroethics is concerned with the ethical, legal and social policy implications of neuroscience ${ }^{11}$. Fundamental ethical principles relevant for neuroethics are patient autonomy (i.e., the patient has a choice of treatment, gets information about different treatment options, as reflected in the informed consent procedure), patient well-being (physicians should prevent and remove harms, and weigh and balance possible benefits of an action against possible risks) and justice (priority should be given to patients who are most seriously impaired and who will benefit most from the intervention, patients should get access to the best treatment). These ethical criteria are analyzed in the context of the current clinical application of neuromodulation treatments in treatment-resistant depression.

\section{Treatments}

Electroconvulsive therapy

Method. ECT was developed in 1938 and is the oldest and best evaluated neuromodulation therapy for treatment-resistant depression. An electrical current is administered to the brain through the scalp. Seizures are induced under general anesthesia and muscle relaxation. Usually, a series of seizures (9-12) are given over several weeks, generally $2-3$ treatments per week.

Mechanism of action. The mechanism of action is not understood, but the induction of a generalized seizure and the postictal suppression $^{12-17}$ are important factors contributing to the antidepressant effect.

Clinical application. ECT is highly effective in treatmentresistant depressive disorders, with $50-80 \%$ of patients achieving remission $^{18,19}$, and is therefore the most effective acute treatment for major depressive disorder ${ }^{20,21}$.

Efficacy. ECT has level I evidence for acute efficacy and relapse prevention, and level II for safety and tolerability ${ }^{22}$ (see Table 1). Transient cognitive side effects, such as postictal confusion and

Table 1. Level of Evidence in Brain Stimulation.

\begin{tabular}{|c|c|c|c|c|c|c|}
\hline Treatment & Invasive & Chronic treatment & Acute efficacy & Long-term efficacy & FDA approval & Safety \\
\hline ECT & & $\begin{array}{l}\text { Maintenance } \\
\text { treatment optional }\end{array}$ & Level 1 & Level 1 & $x$ & Level 2 \\
\hline MST & & $\begin{array}{l}\text { Maintenance } \\
\text { treatment optional }\end{array}$ & $\begin{array}{l}\text { Level } 3 \\
70 \% \text { acute response }\end{array}$ & $\begin{array}{l}\text { Level } 3 \\
50 \% \text { relapse within } \\
6 \text { months }\end{array}$ & $\begin{array}{l}\text { One Phase } 2 \text { trial underway, } \\
\text { see Clinical trials.gov } \\
\text { NCT00973934 }\end{array}$ & Level 3 \\
\hline rTMS & & & Level 1 & Level 3 & $\begin{array}{l}2008 \text { MDD nonresponse } \\
\text { to one medication in the } \\
\text { current episode }\end{array}$ & Level 1 \\
\hline VNS & $x$ & $x$ & Level 2 & Level 2 & $\begin{array}{l}2005 \text { for chronic or recurrent } \\
\text { depression after four } \\
\text { antidepressant trials }\end{array}$ & Level 2 \\
\hline DBS & $x$ & $x$ & Level 3 & Level 3 & & Level 3 \\
\hline
\end{tabular}

DBS, deep brain stimulation; ECT, electroconvulsive therapy; MDD, major depressive disorder; MST, magnetic seizure therapy; rTMS, repetitive transcranial magnetic stimulation; TMS, transcranial magnetic stimulation; VNS, vagus nerve stimulation.

Note. Level of evidence according to 10:

Level 1 requires $>2$ randomized controlled trials and/or meta-analysis with narrow confidence interval;

Level 2 requires $>1$ randomized controlled trial and/or meta-analysis with wide confidence intervals;

Level 3 requires nonrandomized, controlled prospective studies, case series or retrospective studies. 
anterograde amnesia, are frequent and more pronounced in bilateral electrode placement as compared to unilateral electrode placement ${ }^{23,24}$. Up to $55 \%$ of patients report persistent negative cognitive side effects after $\mathrm{ECT}^{25}$.

Ethical aspects. Although very well investigated, effective and safe, ECT is still an underused treatment in treatment-resistant depression $^{26}$ for several reasons. ECT is still stigmatized because of its different use in the past ${ }^{27,28}$ and cognitive side effects are often overestimated, in comparison to cognitive impairment due to depression itself. Clinical staff members are still inadequately trained and face prejudices, such as limitations on the use of ECT in elderly patients. This leads to a reduced availability in hospitals. The idea that every patient should have access to the treatment with the best prognosis is reflected in the ethical principle of justice. For ECT, the ethical principle of justice is not adequately met for the above mentioned reasons.

Current research and outlook. Research has focused on maximizing antidepressant efficacy while minimizing cognitive side effects. Thus, administration techniques (unilateral vs. bilateral stimulation, ultra-brief pulse-width stimulation), the role of postictal depression, depth of anesthesia ${ }^{29,30}$, the separation of effects on cognition and depression ${ }^{31-33}$, and the best algorithm for maintenance therapy are current research questions.

ECT is established as a conventional treatment in treatmentresistant depression with few contraindications. ECT therefore often serves as treatment for the comparison group in studies as the "gold standard" for the evaluation of new treatments (e.g., MST).

\section{Magnetic seizure therapy}

Method. In MST, seizures are induced with magnetic pulses. The clinical procedure (general anesthesia, 9-12 sessions) is similar to ECT. The aim of the development of MST was to minimize cognitive side effects through a more focal induction of seizures ${ }^{34}$.

Mechanism of action. Similar to ECT, the exact mechanism of action is unknown. In MST, only the superficial cortex is exposed during seizure induction, but the seizure generalizes to broader brain regions ${ }^{35}$. Imaging studies have found evidence for changes in glucose metabolism in brain regions that have frequently been reported as dysfunctional in depression ${ }^{36-38}$.

Clinical application. Clinical application is limited to a few study centers worldwide, because a specially modified device is required.

Efficacy. Only data from open-label pilot studies with small sample sizes in a few research sites are actually available. Efficacy seems to be similar to ECT, but possibly with a superior side-effect profile regarding cognition ${ }^{38-43}$ (see Table 1).

Ethical aspects. As long as MST is applied in clinical studies with careful patient selection and information about alternative treatment options is available, the ethical principles of patient autonomy and well-being are fulfilled.
Actually, research in MST is completely controlled by a few companies because special devices are required. In spite of attractive results from small samples, research activities have seemed to diminish. The fear of cognitive side effects is one major obstacle to encouraging patients to undergo seizure therapy. Thus, the development and availability of a potential treatment method with a possible superior side-effect profile is delayed. This contravenes the ethical principle of patient well-being and justice.

Current research and outlook. Best stimulation parameters (e.g., finding the optimal stimulus intensity), the relevance of seizure threshold titration, and the development of devices and coils are current research foci. One controlled double-blind trial $(n=20)$ is underway (Lisanby et al., see the Registry on ClinicalTrials.gov NCT00973934 https://clinicaltrials.gov/). Long-term blinded and controlled studies with larger samples, and studies into the evaluation of relapse rates and the role of maintenance MST are needed.

\section{Transcranial magnetic stimulation}

Method. Transcranial magnetic stimulation (TMS) is a noninvasive therapy option which can be applied to outpatients with treatmentresistant depression.

During repetitive TMS, a fast series of brief pulses of strong magnetic stimuli are applied to the brain. Deep repetitive TMS is a modification of repetitive TMS which can reach deeper cortical regions with a special coil ${ }^{44}$. The $\mathrm{H} \mathrm{Coil}^{45}$ is the only coil whose safety and effectiveness has been tested. This coil is able to change cortical excitability at a depth of up to $6 \mathrm{~cm}^{46}$.

Mechanism of action. Repetitive TMS and deep repetitive TMS produce changes in neuronal excitability. The magnetic field generated at the coil passes unimpeded through the scalp and skull. An electrical current is induced in the underlying tissue which modulates neural activity ${ }^{47}$. Depending on the parameters of stimulation, cortical excitability can be increased or decreased ${ }^{48}$.

Clinical application. After the identification of the motor threshold, the coil is moved from the motor cortex to the specific target cortical region. In the treatment of major depressive disorder, the target area is usually the left dorsolateral prefrontal $\operatorname{cortex}^{49-51}$. In contrast to ECT or MST, no general anesthesia is required. Patients and TMS operators should wear earplugs during TMS. Usually, 10-30 treatment sessions of 15-45 minutes are administered daily in an outpatient setting.

Efficacy. There is evidence for repetitive TMS either as a monoor add-on therapy for the treatment of moderate treatmentresistant depression (evidence level I) ${ }^{52}$. In 2008, repetitive TMS was approved by the FDA for the treatment of moderate treatmentresistant depression.

Several studies have investigated the efficacy of deep repetitive TMS in patients suffering from treatment-resistant depression ${ }^{49-51,53-57}$. Deep repetitive TMS seems to be an effective and safe treatment for patients with treatment-resistant depression (see Table 1). 
Side effects. Overall, repetitive TMS is seen as safe without enduring side effects: no long-term neurological, cognitive, or cardiovascular side effects are reported ${ }^{58-61}$. Transient headache is the most common side effect after repetitive TMS.

Similar to repetitive TMS, deep repetitive TMS is considered a safe treatment. Scalp discomfort, transient headache and dizziness, insomnia, perceiving an odd smell, numbness in the right temporal and right cervical zone, and (in single cases) generalized seizures have been reported ${ }^{44}$.

There is no long-term evidence for either repetitive TMS or deep repetitive TMS because most studies are limited to 6-12 weeks (see 22 for a comprehensive review of TMS studies).

Ethical aspects. Although, the FDA has approved repetitive TMS (level I evidence for acute efficacy), this treatment is only available in special centers and patients do not have the opportunity to choose this therapy option even though its clinical evidence has been proven. Both repetitive TMS and deep repetitive TMS seem to have lower response rates in treatment-resistant depression as compared to ECT (Lipsman, Sankar et al. 2014), but the side-effect profile seems superior. In addition, TMS can be performed in an outpatient setting without anesthesia. Patients should be given the choice between a less effective but also less risky therapy, and a therapy with a higher risk for side effects and higher efficacy. This fits with the ethical criterion of justice and patient autonomy.

Current research and outlook. Current research foci in TMS are the effect of low- and high-frequency stimulation and laterality issues, and optimizing TMS pulse and train parameters, as well as the influence of the characteristics of the TMS pulse itself (with the help of the controllable pulse TMS device). Little is known about combination therapy (e.g., pharmacotherapy, psychotherapy).

\section{Vagus nerve stimulation}

Method. VNS is an invasive brain stimulation method. A small electrical pulse is administered with an implanted neurostimulator to a bipolar electrode, surgically implanted at the left vagus. The pulse generator is implanted under the skin of the left chest. Intermittent electrical currents are sent from the generator to the vagus nerve and via the nucleus tractus solitarius to various regions of the brain. Usually, electrical pulses that last about 30 seconds are forwarded about every 5 minutes from the generator to the vagus nerve; other parameters consist of a current intensity of 0.20 to $2.50 \mathrm{~mA}$, a pulse width of $500 \mathrm{~ms}$ and a pulse frequency of $20 \mathrm{~Hz}$.

Mechanism of action. Brain imaging studies have demonstrated metabolic changes in the prefrontal cortex and in limbic structures relevant to mood regulation ${ }^{62}$, possibly through the modulation of monoaminergic neurotransmission ${ }^{63}$.

Clinical application. VNS, in its current form, is a chronic treatment. During the first months of treatment, the best stimulation parameters have to be selected; therefore, regular visits are required at the beginning of therapy. In the long-term, yearly checkups are advised to ensure the functioning of the device (e.g., battery exhaustion and lead connection) and to adjust parameters if necessary.

Efficacy. In 2005, the FDA-approved VNS therapy for the adjunctive long-term treatment of chronic or recurrent depression for those patients who have not had an adequate response to two or more antidepressant treatments.

Long-term effects were significantly superior by outcomes in comparison to patients receiving treatment as usual. However, VNS therapy is more effective in patients with moderate but not extreme levels of resistance ${ }^{64,65}$ (see Table 1).

Side effects. Possible side-effects of VNS therapy are: an infection at the device, a hoarse voice, cough, and shortness of breath, as well as difficulties in swallowing ${ }^{64,65}$.

Ethical aspects. Although clinical efficacy has been proven and is superior to non-invasive treatments (e.g., repetitive TMS), VNS is not available for many patients as insurance companies only cover the cost for the surgery and not for the (psychiatric and neurosurgical) long-term treatment. For financial reasons, VNS is therefore unattractive to hospitals. This situation contravenes the criteria of justice, well-being and autonomy. In addition, the opportunity to conduct research is limited and important safety aspects (e.g., predictors of response and long-term side-effects) are not assessed sufficiently. This again contravenes the criterion of patient well-being.

Current research and outlook. Research in VNS is limited because of the above mentioned financial restraints. Predictors of response (prior response to ECT, age, subtypes of depression etc.) and longterm safety (above 3 years) can only be inferred from its use in the treatment of epilepsy.

\section{Deep brain stimulation}

Method. DBS is the most invasive neuromodulation technique because it involves the stereotactic implantation of unilateral or bilateral electrodes in the brain, connected to a permanently implanted, battery-powered neurostimulator. Usually, a pair of electrodes are placed into a specific brain region assumed to be involved in mood regulation. Constant stimulation can be adjusted with the parameters of voltage, pulse width, frequency and shape of the electric field.

Mechanism of action. The effect of DBS on the brain is far from being understood. Stimulation parameters (frequency, amplitude, pulse width, duration) also clearly have an impact on the effect. With commonly used parameters, a relatively large volume of neural tissue is influenced ${ }^{66}$.

Functional neuroimaging data have demonstrated that DBS changes the activity of brain areas far beyond the targeted region. Thus complex neural networks are putatively modulated ${ }^{66-68}$. 
In hypothesis-guided approaches, several brain structures are targets of DBS: the subgenual cingulate gyrus $(\mathrm{Cg} 25)^{32,67,69}$, the anterior limb of the capsula interna (ALIC) ${ }^{70,71}$ and the nucleus accumbens (Nacc) $)^{68,72}$, and the supero-lateral branch of the medial forebrain bundle (slMFB) $)^{73}$.

Clinical application. DBS is only available for a highly selected group of patients suffering from very therapy-resistant depression in clinical studies in a few centers worldwide. Launching a DBS study requires a specialized multidisciplinary team, including a psychiatrist, psychologist, and neurosurgeon, and the possibility for a long-term follow-up.

Efficacy. In small pilot studies, an antidepressant effect of DBS was described: a reduction of symptoms of greater than $50 \%$ was reached in about $50 \%$ of the patients after 12 months of DBS treatment ${ }^{70,74-78}$. First results have found superior response rates in the slMFB (more rapid effects and $>70 \%$ response rates after 3 months ${ }^{79}$ and after 12 months ${ }^{79}$ ), but long-term data and larger samples are required for efficacy evaluation. First small studies with sham stimulation found conflicting results concerning placebo effects ${ }^{79,80}$ (see Table 1).

Side effects. The adverse reactions caused by DBS can be differentiated in first effects related to the surgical implantation procedure itself (e.g., bleeding, infection) and second effects related to the stimulation which depend on the target site of stimulation (e.g., paresthesia, muscle contraction, dysarthria, and diplopia, hypomania, anxiety). The former are rare (i.e., risk of seizure 1-3\%, of bleeding $1-5 \%$, and of infection 2-25\%), the latter are reversible with a parameter adjustment. DBS seems to have neutral-to-positive effects regarding cognition ${ }^{33,74,75}$.

Ethical aspects. Few treatment approaches in psychiatry have initiated as much ethical debate as DBS. Major issues concerning patient autonomy are: the manipulation of human personality with $\mathrm{DBS}^{81}$, a sudden disruption of the patient's biography ${ }^{82}$, and the ability of patients with treatment-resistant depression to give informed consent ${ }^{83}$.

Regarding well-being, the induction of new psychiatric symptoms (e.g., hypomania symptoms ${ }^{84}$ or high-risk behavior ${ }^{85}$ ) is debatable. Because DBS is a high-risk intervention, patients have to be carefully selected and, as long as the optimal target has not been established and efficacy is questionable, only patients resistant to all conventional treatment approaches (including ECT) should be selected for studies. Careful individual risk-benefit ratios are necessary to ensure the criterion of patient well-being.

The idea of possibly enhancing cognitive functions is important in terms of the criterion of justice, although in treatment-resistant depression, the amelioration of cognitive functions could be discussed in relation to a prior dysfunction in cognition caused by the depression $^{81}$

DBS is only available in specialized centers for a few, highly selected, therapy-resistant patients. In addition, DBS is very expensive and dominated by a few companies, and little investment from the government exists. These factors restrict availability but should be seen in the light of patient well-being (e.g., to prevent harm from untrained staff, and random application before safety is assessed).

Current research and outlook. DBS is a treatment method in the early phase of evaluation (level III). Therefore, efficacy and safety have to be assessed in sham stimulation control designs. Due to ethical reasons, it is difficult to install a randomized design. Current research questions are the best target site, parameter adjustment protocols, the predictive value of acute stimulation effects, and other predictors of response (e.g., depression subclusters, length and number of depressive episodes, former response to ECT). Furthermore, imaging studies are necessary to elucidate the mode of action.

\section{Summary and outlook}

In the last two decades, many neuromodulation techniques have evolved at different levels of evidence. Noninvasive techniques (ECT, MST and TMS) and invasive techniques (VNS and DBS) with different safety profiles, as well as limited data on long-term efficacy and reduced availability, make it a challenge to select an appropriate treatment for patients with treatment-resistant depression.

Illness chronicity, severity of the current episode, as well as nonresponse to other treatment approaches and fear of side effects, should be considered among other factors. After all, it is also the patient's choice if an evaluated treatment with a very good shortterm efficacy but inferior side-effect profile (e.g., ECT) is preferred, rather than a more experimental treatment with a possibly favorable side-effect profile (e.g., MST), or an experimental treatment with lower response rates (e.g., TMS). For more resistant courses of treatment-resistant depression (e.g., after non-response to TMS and ECT), VNS can be an option. At the current stage of research, DBS should only be offered to extremely treatment-resistant patients with limited psychiatric comorbidity within clinical studies in order to protect patient well-being.

If available, the treatment associated with the best side-effect profile and efficacy should be selected. Reality shows that, due to reduced availability and lacking long-term efficacy data, most patients with treatment-resistant depression face a trial-and-error approach to therapeutics. This contravenes the ethical criteria of patient autonomy and justice. There is minimal guidance for clinicians concerning long-term management of these complex patients. This is inefficient, costly, and associated with poor outcomes, and patients are facing a reduced quality of life. It is therefore necessary to support long-term research in neuromodulation for treatment-resistant depression and to conduct large sample randomized control trials. This only seems possible with public funding in addition to company-sponsored trials. This would allow us to raise the level of evidence for neuromodulation treatments as promising therapy options for treatment-resistant depression.

\section{Abbreviations}

DBS, deep brain stimulation; ECT, electroconvulsive therapy; MST, magnetic seizure therapy; slMFB, supero-lateral branch of the medial forebrain bundle; TMS, transcranial magnetic stimulation; VNS, vagus nerve stimulation. 


\section{Competing interests}

No funding specifically for conducting this review has been obtained. TS received partial funding for an investigator-initiated study on DBS for major depression from Medtronic Inc. TS is chair of the project group Deep Brain Stimulation in Psychiatry: Guidance for Responsible Research and Application, funded by the Volkswagen Foundation (Hanover, Germany). TS and BB are members of the working group Neuromodulation of the German Research Foundation.

\section{Grant information}

The author(s) declared that no grants were involved in supporting this work.
1. Rush AJ, Trivedi MH, Wisniewski SR, et al.: Acute and longer-term outcomes in depressed outpatients requiring one or several treatment steps: a STAR ${ }^{\star} D$ report. Am J Psychiatry. 2006; 163(11): 1905-17.

PubMed Abstract | Publisher Full Text

2. Rush $A J$, Warden $D$, Wisniewski $S R$, et al:: $S_{T A R}{ }^{\star} D$ : revising conventional wisdom. CNS Drugs. 2009; 23(8): 627-47. PubMed Abstract | Publisher Full Text

3. Sackeim HA: The definition and meaning of treatment-resistant depression. J Clin Psychiatry. 2001; 62(Suppl 16): 10-7. PubMed Abstract

4. Thase ME, Rush AJ: When at first you don't succeed: sequential strategies for antidepressant nonresponders. J Clin Psychiatry. 1997; 58(Suppl 13): 23-9. PubMed Abstract

5. Schlaepfer TE, Agren $\mathrm{H}$, Monteleone $\mathrm{P}$, et al.: The hidden third: improving outcome in treatment-resistant depression. J Psychopharmacol. 2012; 26(5): 587-602.

PubMed Abstract | Publisher Full Text

6. Folstein MF, Folstein SE, McHugh PR: "Mini-mental state". A practical method for grading the cognitive state of patients for the clinician. $J$ Psychiatric Res. 1975; 12(3): 189-98.

PubMed Abstract | Publisher Full Text

7. Nierenberg AA: Long-term management of chronic depression. J Clin Psychiatry. 2001; 62(Suppl 6): 17-21.

PubMed Abstract

8. F Fekadu A, Wooderson SC, Markopoulo K, et al:: What happens to patients with treatment-resistant depression? A systematic review of medium to long term outcome studies. J Affect Disord. 2009; 116(1-2): 4-11.

PubMed Abstract | Publisher Full Text | F1000 Recommendation

9. Warden $\mathrm{D}$, Rush AJ, Wisniewski SR, et al:: What predicts attrition in second step medication treatments for depression?: a STAR ${ }^{\star} D$ Report. Int $J$ Neuropsychopharmacol. 2009; 12(4): 459-73.

PubMed Abstract | Publisher Full Text

10. Kennedy SH, Lam RW, Parikh SV, et al.: Canadian Network for Mood and Anxiety Treatments (CANMAT) clinical guidelines for the management of major depressive disorder in adults. Introduction. J Affect Disord. 2009; 117(Suppl 1): S1-2.

PubMed Abstract | Publisher Full Text

11. Illes J, Bird SJ: Neuroethics: a modern context for ethics in neuroscience. Trends Neurosci. 2006; 29(9): 511-7.

PubMed Abstract | Publisher Full Text | Free Full Text

12. Weiner RD, Krystal AD: EEG monitoring and management of electrically induzed seizures. Washington, DC, American Psychiatric Press, 1993.

13. Krystal $A D$, Weiner RD, Coffey CE: The ictal EEG as a marker of adequate stimulus intensity with unilateral ECT. J Neuropsychiatry Clin Neurosci. 1995; 7(3): 295-303

PubMed Abstract | Publisher Full Text

14. Sackeim HA: The anticonvulsant hypothesis of the mechanisms of action of ECT: current status. J ECT 1999; 15(1): 5-26. PubMed Abstract | Publisher Full Text

15. F Krystal $A D$, West M, Prado R, et al.: EEG effects of ECT: implications for rTMS. Depress Anxiety. 2000; 12(3): 157-65.

PubMed Abstract | Publisher Full Text | F1000 Recommendation

16. F Luber B, Nobler MS, Moeller JR, et al:: Quantitative EEG during seizures induced by electroconvulsive therapy: relations to treatment modality and clinical features. II. Topographic analyses. J ECT. 2000; 16(3): 229-43. PubMed Abstract | Publisher Full Text | F1000 Recommendation

17. F Nobler MS, Luber B, Moeller JR, et al:: Quantitative EEG during seizures induced by electroconvulsive therapy: relations to treatment modality and clinical features. I. Global analyses. J ECT. 2000; 16(3): 211-28 PubMed Abstract | Publisher Full Text | F1000 Recommendation

18. F Sackeim HA, Haskett RF, Mulsant BH, et al:: Continuation pharmacotherapy in the prevention of relapse following electroconvulsive therapy: a randomized controlled trial. JAMA. 2001; 285(10): 1299-307.

PubMed Abstract | Publisher Full Text | F1000 Recommendation

19. $\mathrm{F}$ Khalid N, Atkins M, Tredget J, et al.: The effectiveness of electroconvulsive therapy in treatment-resistant depression: a naturalistic study. J ECT. 2008; 24(2): 141-5.

PubMed Abstract | Publisher Full Text | F1000 Recommendation

20. APA, Ed: Diagnostic and Statistical Manual of Mental Disorders (DSM IV) Washington DC, American Psychiatric Association, 1994.

Reference Source

21. F Ebmeier KP, Donaghey C, Steele JD: Recent developments and current controversies in depression. Lancet. 2006; 367(9505): 153-67. PubMed Abstract | Publisher Full Text | F1000 Recommendation

22. Lipsman N, Sankar T, Downar J, et al.: Neuromodulation for treatment-refractory major depressive disorder. CMAJ. 2014; 186(1): 33-9 PubMed Abstract | Publisher Full Text | Free Full Text

23. Donahue $\mathrm{AB}$ : Electroconvulsive therapy and memory loss: a personal journey. JECT. 2000; 16(2): 133-43.

PubMed Abstract

24. Datka W, Siwek M, Dudek D, et al.: [Working memory disturbances in patients with major depression after ECT treatment]. Psychiatr Pol. 2007; 41(3): 339-49.

PubMed Abstract

25. Rose D, Fleischmann $\mathrm{P}$, Wykes $\mathrm{T}$, et al.: Patients' perspectives on electroconvulsive therapy: systematic review. BMJ. 2003; 326(7403): 1363. PubMed Abstract | Publisher Full Text | Free Full Text

26. Rapoport MJ, Mamdani M, Herrmann N: Electroconvulsive therapy in older adults: 13-year trends. Can J Psychiatry. 2006; 51(9): 616-9. PubMed Abstract

27. Payne NA, Prudic J: Electroconvulsive therapy: Part I. A perspective on the evolution and current practice of ECT. J Psychiatr Pract. 2009; 15(5): 346-68. PubMed Abstract | Publisher Full Text | Free Full Text

28. Payne NA, Prudic J: Electroconvulsive therapy: Part II: a biopsychosocial perspective. J Psychiatr Pract. 2009; 15(5): 369-90. PubMed Abstract | Publisher Full Text | Free Full Text

29. Kayser S, Bewernick BH, Hurlemann R, et al:: Comparable seizure characteristics in magnetic seizure therapy and electroconvulsive therapy for major depression. Eur Neuropsychopharmacol. 2013; 23(11): 1541-50. PubMed Abstract | Publisher Full Text

30. Soehle M, Kayser S, Ellerkmann RK, et al:: Bilateral bispectral index monitoring during and after electroconvulsive therapy compared with magnetic seizure therapy for treatment-resistant depression. Br J Anaesth. 2014; 112(4): 695-702. PubMed Abstract | Publisher Full Text

31. Austin MP, Mitchell P, Goodwin GM: Cognitive deficits in depression: possible implications for functional neuropathology. Br J Psychiatry. 2001; 178(3): 200-6. PubMed Abstract | Publisher Full Text

32. McNeely HE, Mayberg HS, Lozano AM, et al:: Neuropsychological impact of Cg25 deep brain stimulation for treatment-resistant depression: preliminary results over 12 months. J Nerv Ment Dis. 2008; 196(5): 405-10. PubMed Abstract | Publisher Full Text

33. Grubert C, Hurlemann R, Bewernick BH, et al:: Neuropsychological safety of nucleus accumbens deep brain stimulation for major depression: effects of 12-month stimulation. World J Biol Psychiatry. 2011; 12(7): 516-27. PubMed Abstract | Publisher Full Text

34. Lisanby SH, Schlaepfer TE, Fisch HU, et al.: Magnetic seizure therapy of major 
depression. Arch Gen Psychiatry. 2001; 58(3): 303-5

PubMed Abstract | Publisher Full Text

35. F Rowny SB, Cycowicz YM, McClintock SM, et al.: Differential heart rate response to magnetic seizure therapy (MST) relative to electroconvulsive therapy: a nonhuman primate model. Neuroimage. 2009; 47(3): 1086-91. PubMed Abstract | Publisher Full Text | Free Full Text | F1000 Recommendation

36. Kosel M, Frick C, Lisanby SH, et al.: Magnetic seizure therapy improves mood in refractory major depression. Neuropsychopharmacology. 2003; 28(11): 2045-8. PubMed Abstract | Publisher Full Text

37. F Hoy KE, Thomson RH, Cherk M, et al:: Effect of magnetic seizure therapy on regional brain glucose metabolism in major depression. Psychiatry Res. 2013; 211(2): 169-75.

PubMed Abstract | Publisher Full Text | F1000 Recommendation

38. Kayser S, Bewernick BH, Matusch A, et al:: Magnetic seizure therapy in treatment-resistant depression: clinical, neuropsychological and metabolic effects. Psychol Med. 2015; 45(5): 1073-92.

PubMed Abstract | Publisher Full Text

39. Lisanby SH, Luber B, Schlaepfer TE, et al:: Safety and feasibility of magnetic seizure therapy (MST) in major depression: randomized within-subject comparison with electroconvulsive therapy. Neuropsychopharmacology. 2003; 28(10): 1852-65

PubMed Abstract | Publisher Full Text

40. F White $P F$, Amos $Q$, Zhang $Y$, et al:: Anesthetic considerations for magnetic seizure therapy: a novel therapy for severe depression. Anesth Analg. 2006; 103(1): 76-80, table of contents.

PubMed Abstract | Publisher Full Text | F1000 Recommendation

41. Kayser S, Bewernick B, Axmacher N, et al:: Magnetic seizure therapy of treatment-resistant depression in a patient with bipolar disorder. J ECT. 2009; 25(2): 137-40.

PubMed Abstract | Publisher Full Tex

42. F Kayser S, Bewernick BH, Grubert C, et al:: Antidepressant effects, of magnetic seizure therapy and electroconvulsive therapy, in treatment-resistant depression. J Psychiatr Res. 2011; 45(5): 569-76.

PubMed Abstract | Publisher Full Text | F1000 Recommendation

43. F Fitzgerald PB, Hoy KE, Herring SE, et al.: Pilot study of the clinical and cognitive effects of high-frequency magnetic seizure therapy in major depressive disorder. Depress Anxiety. 2013; 30(2): 129-36. PubMed Abstract | Publisher Full Text | F1000 Recommendation

44. Bersani FS, Girardi N, Sanna L, et al.: Deep transcranial magnetic stimulation for treatment-resistant bipolar depression: a case report of acute and maintenance efficacy. Neurocase. 2013; 19(5): 451-7. PubMed Abstract | Publisher Full Text

45. F Roth $\mathrm{Y}$, Zangen A, Hallett M: A coil design for transcranial magnetic stimulation of deep brain regions. J Clin Neurophysiol. 2002; 19(4): 361-70. PubMed Abstract | Publisher Full Text | F1000 Recommendation

46. F Roth Y, Amir A, Levkovitz Y, et al.: Three-dimensional distribution of the electric field induced in the brain by transcranial magnetic stimulation using figure-8 and deep H-coils. J Clin Neurophysiol. 2007; 24(1): 31-8. PubMed Abstract | Publisher Full Text | F1000 Recommendation

47. George MS, Nahas Z, Lisanby SH, et al:: Transcranial magnetic stimulation. Neurosurg Clin N Am. 2003; 14(2): 283-301.

PubMed Abstract | Publisher Full Text

48. Fitzgerald PB, Fountain S, Daskalakis ZJ: A comprehensive review of the effects of rTMS on motor cortical excitability and inhibition. Clin Neurophysiol. 2006 117(12): 2584-96.

PubMed Abstract | Publisher Full Text

49. Levkovitz $Y$, Harel EV, Roth $Y$, et al.: Deep transcranial magnetic stimulation over the prefrontal cortex: evaluation of antidepressant and cognitive effects in depressive patients. Brain Stimul. 2009; 2(4): 188-200.

PubMed Abstract | Publisher Full Text

50. Levkovitz Y, Sheer A, Harel EV, et al.: Differential effects of deep TMS of the prefrontal cortex on apathy and depression. Brain Stimul. 2011; 4(4): 266-74. PubMed Abstract | Publisher Full Text

51. Harel EV, Rabany L, Deutsch L, et al:: $\mathrm{H}$-coil repetitive transcranial magnetic stimulation for treatment resistant major depressive disorder: An 18-week continuation safety and feasibility study. World J Biol Psychiatry. 2014; 15(4): 298-306.

PubMed Abstract | Publisher Full Text

52. F Gaynes BN, Lloyd SW, Lux L, et al.: Repetitive transcranial magnetic stimulation for treatment-resistant depression: a systematic review and meta-analysis. J Clin Psychiatry. 2014; 75(5): 477-89; quiz 489. PubMed Abstract | Publisher Full Text | F1000 Recommendation

53. F Levkovitz $\mathrm{Y}$, Roth $\mathrm{Y}$, Harel EV, et al.: A randomized controlled feasibility and safety study of deep transcranial magnetic stimulation. Clin Neurophysiol. 2007; 118(12): 2730-44.

PubMed Abstract | Publisher Full Text | F1000 Recommendation

54. F Rosenberg O, Zangen A, Stryjer R, et al.: Response to deep TMS in depressive patients with previous electroconvulsive treatment. Brain Stimul. 2010; 3(4): 211-7.

PubMed Abstract | Publisher Full Text | F1000 Recommendation

55. $\mathrm{F}$ Harel EV, Zangen $\mathrm{A}$, Roth $\mathrm{Y}$, et al.: $\mathrm{H}$-coil repetitive transcranial magnetic stimulation for the treatment of bipolar depression: an add-on, safety and feasibility study. World J Biol Psychiatry. 2011; 12(2): 119-26. PubMed Abstract | Publisher Full Text | F1000 Recommendation

56. F Isserles $\mathrm{M}$, Rosenberg $\mathrm{O}$, Dannon $\mathrm{P}$, et al.: Cognitive-emotional reactivation during deep transcranial magnetic stimulation over the prefrontal cortex of depressive patients affects antidepressant outcome. J Affect Disord. 2011; 128(3): 235-42.

PubMed Abstract | Publisher Full Text | F1000 Recommendation

57. F Rosenberg O, Isserles M, Levkovitz $\mathrm{Y}$, et al.: Effectiveness of a second deep TMS in depression: a brief report. Prog Neuropsychopharmacol Biol Psychiatry. 2011; 35(4): 1041-4.

PubMed Abstract | Publisher Full Text | F1000 Recommendation

58. F Little JT, Kimbrell TA, Wassermann EM, et al.: Cognitive effects of 1- and 20-hertz repetitive transcranial magnetic stimulation in depression: preliminary report. Neuropsychiatry Neuropsychol Behav Neurol. 2000; 13(2): 119-24. PubMed Abstract | F1000 Recommendation

59. Schulze-Rauschenbach SC, Harms U, Schlaepfer TE, et al:: Distinctive neurocognitive effects of repetitive transcranial magnetic stimulation and electroconvulsive therapy in major depression. Br J Psychiatry. 2005; 186: 410-6. PubMed Abstract | Publisher Full Text

60. F Janicak PG, O'Reardon JP, Sampson SM, et al:: Transcranial magnetic stimulation in the treatment of major depressive disorder: a comprehensive summary of safety experience from acute exposure, extended exposure, and during reintroduction treatment. J Clin Psychiatry. 2008; 69(2): 222-32. PubMed Abstract | Publisher Full Text | F1000 Recommendation

61. Schlaepfer TE, George MS, Mayberg H: WFSBP Guidelines on Brain Stimulation Treatments in Psychiatry. World J Biol Psychiatry. 2010; 11(1): 2-18. PubMed Abstract | Publisher Full Text

62. F Drevets WC, Bogers W, Raichle ME: Functional anatomical correlates of antidepressant drug treatment assessed using PET measures of regional glucose metabolism. Eur Neuropsychopharmacol. 2002; 12(6): 527-44. PubMed Abstract | Publisher Full Text | F1000 Recommendation

63. F Dorr AE, Debonnel G: Effect of vagus nerve stimulation on serotonergic and noradrenergic transmission. J Pharmacol Exp Ther. 2006; 318(2): 890-8. PubMed Abstract | Publisher Full Text | F1000 Recommendation

64. F Nahas Z, Marangell LB, Husain MM, et al:: Two-year outcome of vagus nerve stimulation (VNS) for treatment of major depressive episodes. $J$ Clin Psychiatry. 2005; 66(9): 1097-104.

PubMed Abstract | Publisher Full Text | F1000 Recommendation

65. Schlaepfer TE, Frick C, Zobel A, et al:: Vagus nerve stimulation for depression: efficacy and safety in a European study. Psychol Med. 2008; 38(5): 651-61. PubMed Abstract | Publisher Full Text

66. F Kringelbach ML, Jenkinson N, Owen SL, et al.: Translational principles of deep brain stimulation. Nat Rev Neurosci. 2007; 8(8): 623-35. PubMed Abstract | Publisher Full Text | F1000 Recommendation

67. F Mayberg HS, Lozano AM, Voon V, et al.: Deep brain stimulation for treatment-resistant depression. Neuron. 2005; 45(5): 651-60. PubMed Abstract | Publisher Full Text | F1000 Recommendation

68. Bewernick BH, Hurlemann R, Matusch A, et al:: Nucleus accumbens deep brain stimulation decreases ratings of depression and anxiety in treatment-resistan depression. Biol Psychiatry. 2010; 67(2): 110-6.

PubMed Abstract | Publisher Full Text

69. F Lozano AM, Mayberg HS, Giacobbe P, et al:: Subcallosal cingulate gyrus deep brain stimulation for treatment-resistant depression. Biol Psychiatry. 2008; 64(6): 461-7.

PubMed Abstract | Publisher Full Text | F1000 Recommendation

70. F Malone DA Jr, Dougherty DD, Rezai AR, et al.: Deep brain stimulation of the ventral capsule/ventral striatum for treatment-resistant depression. Biol Psychiatry. 2009; 65(4): 267-75.

PubMed Abstract | Publisher Full Text | Free Full Text | F1000 Recommendation

71. Malone DA Jr: Use of deep brain stimulation in treatment-resistant depression. Cleve Clin J Med. 2010; 77(Suppl 3): S77-80. PubMed Abstract | Publisher Full Text

72. F Schlaepfer TE, Cohen MX, Frick C, et al:: Deep brain stimulation to reward circuitry alleviates anhedonia in refractory major depression. Neuropsychopharmacology. 2008; 33(2): 368-77.

PubMed Abstract | Publisher Full Text | F1000 Recommendation

73. Schlaepfer TE, Bewernick BH, Kayser S, et al:: Deep brain stimulation of the human reward system for major depression--rationale, outcomes and outlook. Neuropsychopharmacology. 2014; 39(6): 1303-14.

PubMed Abstract | Publisher Full Text | Free Full Text

74. F Kennedy SH, Giacobbe P, Rizvi SJ, et al.: Deep brain stimulation for treatment-resistant depression: follow-up after $\mathbf{3}$ to 6 years. Am J Psychiatry. 2011; 168(5): 502-10.

PubMed Abstract | Publisher Full Text | F1000 Recommendation

75. Bewernick BH, Kayser S, Sturm V, et al.: Long-term effects of nucleus accumbens deep brain stimulation in treatment-resistant depression: evidence for sustained efficacy. Neuropsychopharmacology. 2012; 37(9): 1975-85. PubMed Abstract | Publisher Full Text | Free Full Text

76. F Holtzheimer PE, Kelley ME, Gross RE, et al:: Subcallosal cingulate deep 
brain stimulation for treatment-resistant unipolar and bipolar depression. Arch Gen Psychiatry. 2012; 69(2): 150-8.

PubMed Abstract | Publisher Full Text | Free Full Text | F1000 Recommendation

77. F Lozano AM, Giacobbe P, Hamani C, et al:: A multicenter pilot study of subcallosal cingulate area deep brain stimulation for treatment-resistant depression. J Neurosurg. 2012; 116(2): 315-22.

PubMed Abstract | Publisher Full Text | F1000 Recommendation

78. F Puigdemont D, Pérez-Egea R, Portella MJ, et al:: Deep brain stimulation of the subcallosal cingulate gyrus: further evidence in treatment-resistant major depression. Int J Neuropsychopharmacol. 2012; 15(1): 121-33.

PubMed Abstract | Publisher Full Text | F1000 Recommendation

79. Schlaepfer TE: Rewiring faulty circuits-the promise of deep brain stimulation for psychiatry. Euro Global Summit and Medicare Expo on Psychiatry. Barcelona, Spain, OMICS International Conference, 2015. Publisher Full Text

80. Dougherty D, Carpenter L, Bhati M, et al:: 720-A Randomized Sham-Controlled Trial of DBS of the VC/VS for Treatment-Resistant Depression. Biol Psychiatry. 2012; 71(8): 230S.
81. Synofzik M, Schlaepfer TE: Stimulating personality: ethical criteria for deep brain stimulation in psychiatric patients and for enhancement purposes. Biotechnol J. 2008; 3(12): 1511-20.

PubMed Abstract | Publisher Full Text

82. F Gisquet $\mathrm{E}$ : Cerebral implants and Parkinson's disease: a unique form of biographical disruption? Soc Sci Med. 2008; 67(11): 1847-51.

PubMed Abstract | Publisher Full Text | F1000 Recommendation

83. Appelbaum PS, Grisso T, Frank E, et al.: Competence of depressed patients for consent to research. Am J Psychiatry. 1999; 156(9): 1380-4. PubMed Abstract

84. Synofzik M, Schlaepfer TE, Fins JJ: How Happy Is Too Happy? Euphoria, Neuroethics, and Deep Brain Stimulation of the Nucleus Accumbens. AJOB Neurosci. 2012; 3(1): 30-6. Publisher Full Text

85. F Frank MJ, Samanta J, Moustafa AA, et al:: Hold your horses: impulsivity, deep brain stimulation, and medication in parkinsonism. Science. 2007; 318(5854): 1309-12.

PubMed Abstract | Publisher Full Text | F1000 Recommendation 


\section{Open Peer Review}

\section{Current Peer Review Status:}

\section{Editorial Note on the Review Process}

Faculty Reviews are review articles written by the prestigious Members of Faculty Opinions. The articles are commissioned and peer reviewed before publication to ensure that the final, published version is comprehensive and accessible. The reviewers who approved the final version are listed with their names and affiliations.

\section{The reviewers who approved this article are:}

\section{Version 1}

\section{Michael Thase}

Department of Psychiatry, University of Pennsylvania, Philadelphia, PA, USA

Competing Interests: No competing interests were disclosed.

\section{Allan Young} Institute of Psychiatry, King's College London, London, UK

Competing Interests: No competing interests were disclosed.

\section{Pierre Blier}

Institute of Mental Health Research, University of Ottawa, Ottawa, Canada

Competing Interests: No competing interests were disclosed.

The benefits of publishing with F1000Research:

- Your article is published within days, with no editorial bias

- You can publish traditional articles, null/negative results, case reports, data notes and more

- The peer review process is transparent and collaborative

- Your article is indexed in PubMed after passing peer review

- Dedicated customer support at every stage

For pre-submission enquiries, contact research@f1000.com 